The Last Throw of the Dice: Portugal, Rhodesia and South Africa, 1970-74

Author(s): Filipe Ribeiro de Meneses and Robert McNamara

Source: Portuguese Studies, Vol. 28, No. 2 (2012), pp. 201-215

Published by: Modern Humanities Research Association

Stable URL: https://www.jstor.org/stable/10.5699/portstudies.28.2.0201

JSTOR is a not-for-profit service that helps scholars, researchers, and students discover, use, and build upon a wide range of content in a trusted digital archive. We use information technology and tools to increase productivity and facilitate new forms of scholarship. For more information about JSTOR, please contact support@jstor.org.

Your use of the JSTOR archive indicates your acceptance of the Terms \& Conditions of Use, available at https://about.jstor.org/terms 


\title{
The Last Throw of the Dice: Portugal, Rhodesia and South Africa, 1970-74
}

\author{
Filipe Ribeiro de Meneses and \\ ROBERT MCNAMARA
}

\author{
National University of Ireland Maynooth \\ and University of Ulster
}

In the still limited historiography of the late Estado Novo, Portugal is usually portrayed as no longer having any definite strategy when it came to her colonial possessions by the late 1960 s and early 7os. The country is depicted as hanging on to them for no obvious reason other than the fact that the regime's fate was tied to the wars in Africa and so these had to continue, whatever the cost to the local and metropolitan population, to Portugal's finances (even if the recent discovery of oil in Angola, among other positive developments, promised to ease this particular question), and to the country's international reputation. Against this immobility there grew, with time, the notion that there could be no military solution to Portugal's predicament and that, since no political steps were being taken by the government to end the war, the government had to be overthrown - or it must be turned away from its present course. ${ }^{1}$ This political imperative was, of course, a real one: Salazar's nationalistic New State could not admit the loss of the African colonies (or overseas provinces, as they were designated) and continue to exist as if nothing had occurred - even after Salazar's retirement in 1968 and his replacement by Marcello Caetano, who had, earlier in his career, defended a transformation of the empire along federal lines. Thus, all attempts at foreign mediation were rebuffed, and all negotiation with the nationalist movements was curtailed by Lisbon. ${ }^{2}$ How long Portugal

1 These, in a nutshell, would be the viewpoints of, respectively, the Movimento das Forças Armadas, which seized power in April 1974, and António de Spínola, who, according to his most recent biographer, had no intention of removing Marcello Caetano from the Presidency of the Council when he published, earlier that year, the book Portugal e o Futuro, with the approval of his hierarchical superior, General Costa Gomes. See Luís Nuno Rodrigues, Spínola (Lisbon: A Esfera dos Livros, 2010), p. 227. But a desire for change, possibly within a European context, was present as well among the political and economic elites, among whom Newitt found 'a willingness to examine the void that lay beyond the immediate military necessities of counter-insurgency'. See Malyn Newitt, Portugal in Africa (London: Hurst, 1981), p. 244, and António Costa Pinto, O fim do império português (Lisbon: Livros Horizonte, 2001), p. 32.

2 This stance, which undermined António de Spínola's diplomatic actions in Portuguese Guinea, contributing to the General's alienation, is examined in Norrie McQueen, 'Portugal's First Domino: "Pluricontinentalism" and Colonial War in Guiné-Bissau, 1963-1974', Contemporary European History,

Portuguese Studies vol. 28 no. 2 (2012), 201-15

(C) Modern Humanities Research Association 2012 
could maintain this struggle was the subject of much speculation, but British and American assessments of the early 1970 s did not forecast Lisbon's imminent military defeat. However, ongoing research suggests that there was more to the 'bunker' mentality of the military technocrats in charge of Portugal's war effort and their allies in the security services than meets the eye. The aim of this article is to sketch out one potential survival strategy for a colonialist Portugal, never acknowledged in public, because of the political risks it entailed, but real nonetheless. This policy was by no means consensual within the Portuguese armed forces, and in this lack of consensus lies part of the explanation for the divisions present in the higher echelons of the army, navy and air force at the time of the revolution in April 1974.

One of the Portuguese regime's most quoted mottos was 'orgulhosamente sós': 'proudly alone' Portugal supposedly stood, attacked by domestic traitors and foreign aggressors, who disguised themselves as African nationalists but were, ultimately, in the pay of Moscow or Beijing. In reality, however, Portugal was not alone in Africa, at least in southern Africa, where two other whiterule regimes held sway: post-Unilateral Declaration of Independence (UDI) Rhodesia (although, significantly, contacts had been initiated at the time of the Federation of Rhodesia and Nyasaland) and South Africa. The first was not recognized as an independent state by the international community, and was the subject of a rather porous system of economic sanctions; ${ }^{3}$ the second was an international pariah, thanks to its policy of apartheid, but one whose strategic position and financial and economic clout gave it considerable leverage both on the African scene and in the West, especially with Great Britain, which had huge financial investments in the country, and with France, Pretoria's main supplier of arms from 1964 onwards. From a propaganda point of view, therefore, these were not ideal allies, especially when Portugal claimed to be fighting in Africa in order to nurture and develop multiracial societies, along the 'Lusotropicalist' lines identified earlier in the century by Brazilian sociologist Gilberto Freyre. Practical concerns, however, spoke loudest. Rhodesia bordered Mozambique and so too did South Africa: but, in addition, South Africa bordered Rhodesia and, through South West Africa (Namibia), it touched Angola as well. This was thus a territorially contiguous bloc, whose geographical layout and control of vital infrastructure meant that other countries, despite their independence and even their commitment to decolonization and the end of apartheid, were dependent on Pretoria, Salisbury and Lisbon for their economic survival. This

\footnotetext{
8.2 (1999), 209-3o (p. 219).

3 On sanctions-busting see the multiple references in Ian Smith, Bitter Harvest (London: Blake, 2008) and Ken Flower, Serving Secretly: An Intelligence Chief on Record. Rhodesia into Zimbabwe, 1964 to 1981 (London: John Murray, 1987). More recent archive-based assessments include A. S. Mlambo, " "We Have Blood Relations over the Border": South Africa and Rhodesian Sanctions, 1965-1975', African Historical Review, 40.1 (2008), 1-29 and C. R. W. Dietrich “A Climate of Collaboration": The Rhodesian Oil Embargo and Portuguese Diplomacy in Southern Africa, 1965-1967', Itinerário (Leiden), 35.1 (2011), 97-120.
} 
was the case of Botswana, almost completely surrounded by South Africangoverned territory, and of Zambia, whose mineral exports and vital imports had, of necessity, to flow through Portuguese ports. Hastings Banda, the leader of Malawi, a densely populated and desperately poor country, had no hesitation in publically acknowledging his cooperation with the white-run states of the region. ${ }^{4}$

When taken as a whole, moreover, these three countries represented a powerful economic bloc. South Africa's wealth was a given; Rhodesia's was less evident, but rested above all on the country's fertile land, now that most of the defunct Federation's mineral deposits were controlled by Zambia; and the natural resources of Angola and Mozambique were finally, after years of war, being tapped by the international economy. Oil had begun to flow from the Cabinda off-shore oilfields; Diamang, the Belgian-Portuguese diamond concern, had long acted as a state within a state $;{ }^{5}$ and in Mozambique one investment stood head and shoulders above the rest - the giant Cahora Bassa dam, set to provide the entire region with electricity. The Portuguese colonies were also experiencing something new: a sustained bout of white immigration, which transformed cities, notably Luanda and Lourenço Marques, and gave, on the surface, greater solidity to the idea of Portuguese permanence in Africa. ${ }^{6}$

That the three countries in question consulted regularly in order to coordinate their actions has long been known; an Anti-Apartheid pamphlet had alleged it as far back as 1962. ${ }^{7}$ The allegation was not without foundation, since diplomatic, intelligence and military exchanges were increasingly important. In March 1958, Rhodesia's Federal Intelligence and Security Bureau produced a report, entitled 'The Defence of Africa South of the Sahara', which recommended that the Federation take the lead in the creation of an African Treaty Organization, defined as 'a broad alliance of the Powers in Africa dedicated to the ideals of Western and Commonwealth Defence'. A subsequent report, issued the following year, examined the possibility of 'establishing a closer and if necessary Top Secret alliance between Mozambique and Angola and the Federation of Rhodesia and Nyasaland'; it was envisaged that this might eventually be extended to South Africa, and lead to a Confederation of the states

4 G. M. Cockram, Vorster's Foreign Policy (Pretoria: Academica, 1970), pp. 136-45.

5 See T. Cleveland, 'Minors in Name Only: Child Laborers on the Diamond Mines of the Companhia de Diamantes de Angola (Diamang), 1917-1975', Journal of Family History, 35.1 (2009), 91-110, esp. pp. 93-94 for a summary of Diamang's power and influence.

6 The actual number of Portuguese settlers has long been a matter of dispute. Rita Garcia, in her SOS Angola: os dias da ponte aérea (Lisbon: A Oficina do Livro, 2011), p. 19, uses the 1981 census to show that, from 1973 onwards, 505,078 Portuguese returned from the colonies, the majority of them from Angola. Others settled elsewhere, including South Africa, the United States of America, and various countries in South America, notably Brazil.

7 Rosalynde Ainslie, The Unholy Alliance: Verwoerd, Salazar and Welensky (London: Anti-Apartheid Movement, 1962). William Minter correctly stated that, after 1969, the understanding of the threat they faced had 'resulted in common military planning, despite the absence of a public treaty of military cooperation'. Minter, Portuguese Africa and the West (New York: Monthly Review Press, 1972), p. 129. 
involved. ${ }^{8}$ The full contours of this tripartite cooperation, and its development, are only now becoming clear, as material is declassified. Intelligence services and military high commands were closely intertwined and this unity of purpose and views was, if anything, growing as time passed and the military situation worsened. Rhodesian UDI gave this process an important boost, even though Pretoria, unlike Lisbon, was sceptical about its ultimate significance. In February 1969, with Caetano now in power, South African Defence Minister P. W. Botha headed a military delegation which met his Portuguese counterpart, General Sá Viana Rebelo, and representatives of all branches of the Portuguese Armed Forces. The main thrust of Botha's considerations at that summit lay in the need for a 'continuous plan', which might be extended to Rhodesia; Viana Rebelo agreed that a joint effort by the three countries might create a balance capable of keeping the peace in southern Africa. ${ }^{9}$

The key year in this process was 1970, the moment when it accelerated due not only to battlefield pressure on the Portuguese forces, but also the evolving South African domestic political scene. If under Prime Minister Hendrik Verwoerd (1959-66) South Africa's cabinet had acted in concerted fashion, under his successor, John Vorster, the situation was altered dramatically. A struggle for power emerged, pitting doves (the Department of Foreign Affairs and General Hendrik van den Bergh's BOSS - Bureau of State Security), who preached an African form of detente, against hawks (spearheaded by Botha and senior military figures) convinced that southern Africa faced a total onslaught from global communism, against which a total response was required, one which involved cooperation with the Portuguese and Rhodesians, whose northern borders might therefore act as a cordon sanitaire. One of Botha's principal allies was General Charles Allan 'Pops' Fraser (himself a disciple of French strategist General André Beaufre), who over the course of the late 1960 s had been in close contact with the Portuguese military machine. What Fraser saw in Angola and Mozambique troubled him, because it defied counter-insurgency doctrine as it had been elaborated since the Second World War. In March 1970 he produced a well-flagged report on the Portuguese campaign in Angola which, because of its proximity to South West Africa, concerned Pretoria directly. The South West Africa Peoples' Organisation (SWAPO) fighters used territory in the hands of the Movimento Popular de Libertação de Angola (MPLA) and the União Nacional para a Independência Total de Angola (UNITA) to approach and enter South West Africa; halting them became Pretoria's main concern in the region. Largely exonerating the Portuguese military authorities, this report placed the blame for the worsening situation on the civilian administrators, who seemed powerless to improve relations with the African population, leading the latter to support the nationalist movements. If in public Fraser was

8 Oxford, Bodleian Library, Roy Welensky Papers, Box 234, POL.FB.551.

9 Paço de Arcos, Arquivo da Defesa Nacional, Secretaria Geral da Defesa Nacional, Caixa 6179, 'Reunião dos Ministros da Defesa na República da África do Sul e de Portugal. Relato'. 
effusive about Portugal's efforts, in private the South African Defence Forces had very real doubts over the efficacy of the Portuguese war machine, whose failure would dramatically alter the regional balance of power. Also in private, Portuguese military authorities recognized the validity of Fraser's criticism, and were thankful that it had not been more severe. General Almeida Viana, Commander-in-Chief of the Armed Forces in Angola since 1967, wrote to Sá Viana Rebelo, explaining that Fraser had recently referred to the insuficiente instrução, e mesmo à fraca determinação das nossas tropas regulares, e à falta de oportunidade com que por vezes actuam [insufficient instruction, and even the weak resolve of our regular troops, and the sometimes poor timing of their actions]'. Viana added, 'Há que reconhecer-lhe certa razão' [we must recognize that he is partly right]. ${ }^{10}$

Since the hard-pressed Portuguese were increasingly reliant on the South Africans for financial and military help - though asking for it in piecemeal fashion - a new compact was established, using Fraser's report as a battering ram. Support would be continued only if Portugal agreed to a new defensive framework, one which in the long run guaranteed South Africa - the senior military partner - a greater say in the conduct of the war, and which saw the two countries, plus Rhodesia, cooperate across a series of practical fields, first and foremost of which was the pooling of military intelligence. ${ }^{11}$ This was not an alliance, which would have been decried internationally, not least because of Rhodesia's participation, but was termed an 'Exercise', code-named ALCORA. A comparison with the pre-1914 Entente Cordiale is not out of place. Regular staff talks gradually drew the three countries in question into mutual defence obligations should an external aggression occur. ALCORA was agreed to at a bilateral conference between South Africa and Portugal held in Pretoria, in October 1970, and refined at a three-way meeting, also held in Pretoria, in March and April 1971.

By the end of 1971 the basic architecture of ALCORA, as outlined in General Fraser's Defence Plan for Southern Africa, was in place, and meetings of its central bodies - the Advanced Top-Level Committee (ATLC) and the Coordinating Committee - began to occur regularly, as did those of the lower-level Subcommittees. ${ }^{12}$ Political approval was received for the scheduling of meetings, although the extent to which politicians other than the Ministers of Defence were aware of what was happening is not yet clear. ${ }^{13}$ There was a lot

\footnotetext{
10 ADNPdeA, Fundo 1, Série 7, Caixa 32, Top Secret letter, General Almeida Viana to the Minister of National Defence, 26 February 1970.

11 A loan agreement was signed between the South African Reserve Bank and the Portuguese Government on 17 March 1970. A copy is to be found in ADNPdeA, Fundo 1, Série 7, Caixa 32.

12 The subcommittees were devoted to military intelligence; air planning; air defence; air bases; logistics; telecommunications and electronic warfare; communications; counter-insurgency strategy; objectives, command and control; psychological action; and cartography.

13 See, for example, ADNPdeA, Paço de Arcos, Arquivo de Defesa Nacional, SGDN, Caixa 4385, letter, General João de Paiva Brandão (Vice-Chief of Staff of the Portuguese Armed Forces) to Lt. General K. R. Coster (Chief of General Staff, Rhodesia), 2o April 1971.
} 
to get through: the fear of a conventional war in southern Africa against what the ALCORA countries saw as the proxies for international communism (a combination of African states and nationalist movements, coordinated by the Organization of African Unity, suspected of creating a common army) led to the elaboration of a number of reports which had to be constantly reviewed and revised. These covered, for example, the means of securing safe communications and telecommunications; standardized cartography; common logistics; and an estimate of the potential enemy's military strength, its vulnerable points (for aerial attack), and its dealings with the superpowers, as well as China, whose interest in Africa was becoming evident at this stage. ${ }^{14}$ One issue which exercised the minds of ALCORA participants was the Tanzania-Zambia (TANZAM) railway, not only because it would lessen the dependence of the latter country on Portugal, but also because of the presence of thousands of Chinese labourers in Africa who, it was feared, might overnight drop their spades and pick up a rifle. The comings and goings of the delegates to the various meeting places across Portugal and its colonies, Rhodesia and South Africa, were constant, and were becoming increasingly harder to mask; preserving the entire operation's secrecy was therefore a source of permanent concern.

A first move towards more stability was arrived at in the field of military intelligence, through the setting up of the Permanent ALCORA Intelligence Organization (PAIO), based in Salisbury. The previously disseminated intelligence updates had been deemed to be of little use, since they were based on unreliable and out-of-date material; under PAIO the professionalism of these reports increased, as did the quality of the commentary on the raw intelligence. PAIO's creation emboldened South Africa to put the whole of ALCORA on a more permanent footing. At the fifth meeting of the ATLC, held in Pretoria in June 1973, the presiding officer, General van der Riet, reported that discussions between the South African and the Portuguese Defence Ministers had led to the creation of a Permanent ALCORA Planning Organization (PAPO), with Pretoria offering to house the new body and to furnish it with the required administrative services. This was to be a fresh start for the Exercise, with some thirty officers attached full-time to PAPO. By the sixth ATLC meeting, at the end of November 1973, considerable progress had been made. In the intervening period, in September, a tripartite meeting of Defence Ministers had taken place in Pretoria: it was hoped that these would become increasingly routine, the same being true of ALCORA business. Secrecy became harder still to ensure once PAPO had begun to operate, with a skeleton staff, in January 1974. The pressure for public disclosure of ALCORA mounted at this time but was resisted, for the time being, by Portugal.

14 What such a conventional attack might look like was the source of much speculation in ALCORA circles. See SADNPdeA, SGDN, Caixa 4387, 'Setting for Paper Exercise: The threat to the ALCORA territories as on 1 Oct. 1973', produced in November 1972, for an example of how the threat was envisaged. 
At the same time that PAPO was being created, another step was being taken by the ALCORA countries, which pointed towards a further strengthening of relations: the establishment of a mobile military reserve, part of it airborne, which might be sent at a moment's notice to a given trouble spot. ${ }^{15}$ An initial estimate put this at a battalion, with air support, to be in place by the end of 1974, and an airborne brigade, with the required air support, to be ready by mid-to-late 1975; this was an open-ended military commitment, which might continue to grow in accordance with evolving needs. These needs encompassed not only a possible conventional threat - the standard ALCORA bogeyman - but also the ongoing fight against 'terrorism', a theme whose importance grew, especially from 1973 onwards. The proposed force contained a significant paradox: it could only serve to dissuade if it was made public, but the political will to 'go public' on the strategic reserve, and the ALCORA mechanisms which upheld it, was not present, at least in Portugal.

For those Portuguese officers aware of its existence - mostly staff officers in Lisbon or in the military commands at Luanda and Nampula (Mozambique) - Exercise ALCORA became an important part of the war, a guarantee that Portugal would not be defeated, provided that Lisbon's political will to fight remained intact. Accepting unquestioningly a simplistic interpretation of what was happening in Africa, built on Cold War assumptions, they believed that it was indeed possible to score a decisive triumph over the nationalist movements arrayed against them; by 1974, PAPO was being asked to plan for the complete defeat of 'terrorism' in southern Africa.

What did ALCORA actually achieve and could it really have made a difference in the long run? Portuguese Guinea was outside its remit, and there the military situation was increasingly untenable for the Portuguese forces. What impact an outright defeat in that territory might have had for the whole empire was impossible to tell, but it would have been dramatic. In southern Africa the situation was different. First of all, access to South African credit became a staple of Portuguese defence spending. Sá Viana Rebelo informed P. W. Botha in August 1970, that the year's loan 'has helped us to solve certain difficulties in connection with military operations in Angola and Mozambique'. He went on to ask for the loan's terms to be revised. ${ }^{16}$ Some of this funding was diverted towards the maintenance and repair of military hardware, which the Portuguese found particularly difficult to carry out and finance. Militarily the results were mixed. By 1974 what had once been a critical situation in Angola had been reversed, with the Portuguese in control of most of the territory and the MPLA, once the most feared of the nationalist movements in the colony, in disarray. Mozambique, however, was more problematic,

15 An early mention of this force was made at the third meeting of the Aerial Planning Subcommittee, in July 1972. See SADNPdeA SGDN Caixa 5574,' Exercise ALCORA. Third Meeting of Subcommittees APSC. 12 to 21 July [1972]. Minutes of Meeting'.

16 ADNPdeA, Fundo 1, Série 7, Caixa 32, letter, 18 August 1970, General Sá Viana Rebelo to P. W. Botha. 
with the fighting in the Tete district increasing in intensity, and drawing in forces from other sectors to defend the Cahora Bassa complex and its surrounding infrastructure.

What can be said with certainty, at this stage, is that Portugal's reliance on its informal allies continued to grow, and in fact reached a peak shortly before the April 1974 revolution. Early that year, tensions increased with Zaire, a strategically vital country whose relationship with the ALCORA powers was seldom straightforward. The Portuguese believed that Zaire was preparing to invade Angola, or the Cabinda enclave, in direct support of the FNLA. In February, the Commander-in-Chief of the Portuguese forces in Angola, General Luz Cunha, met the South African military leadership, headed by Admiral Biermann, in Cape Town, to discuss 'the latent threat of invasion of the North of Angola and Cabinda by the "Republic of Zaire" Armed Forces and in support of the subversive Organization "FNLA". '17 The perceived threat stemmed from a number of factors: the newfound importance of the FNLA, given the MPLA's military decline; increased Chinese support for both the FNLA and Zaire; Mobutu's desire to be seen as the leader of a victorious assault on southern Africa, in order to garner further political, economic, and military support; and the recent oil crisis, which made Cabinda - impossible to defend - a great prize. There was a scramble in Portugal itself to determine which new units, including tanks and heavy artillery, hitherto alien to the African battlefields, might have to be sent to Angola. The whole process was given a codename, 'Operação Stop'; it culminated in an enormous loan (150 million rands) granted to Lisbon by Pretoria on 8 March 1974. Half of this was spent in the days that preceded the 25 April revolution, some of it on highly sophisticated weapons produced in Israel, including the French-designed Crotale surface-to-air missile system - presumably to shoot down the Mirage fighters which France had recently sold to Zaire. A report on the affair produced in 1975 mentioned contracts being signed for 'a aquisição de material, de que se destacam aquisições em Israel, equipamento "CROTALE” e aviões, helicópteros e equipamentos diversos para a força aérea' [the acquisition of materiel, among which should be highlighted purchases in Israel, of 'CROTALE' equipment and planes, helicopters, and diverse equipment for the air force]. ${ }^{18}$

Further military cooperation took place outside the strict confines of ALCORA, in those areas of Angola and Mozambique which were of direct interest to Portugal's partners. Thus, a detachment of South African helicopters had for quite some time been assisting Portuguese forces in south-east Angola, because of the possible use of MPLA-liberated territory by SWAPO, and Rhodesian forces established agreements with the Portuguese allowing them to

17 ADNPdeA, SGDN, Caixa 6207, letter, 11 March 1974, Silva Cunha to P. W. Botha.

18 ADNPdeA, Série 25, Caixa 57, 'Acordo do empréstimo de 150 milhões de rands firmado com a RAS', 18 September 1975 . The deal was alluded to in very vague terms by Silva Cunha in his interview with José Freire Antunes (January 1995), and published in the latter's A Guerra de África, 1961-1974, 2 vols (Lisbon: Temas e Debates, 1996), I, 333-42. 
intervene in the Tete district of Mozambique, used by ZANU fighters as a way into Rhodesia. These agreements were the source of considerable tension. ${ }^{19}$

International cooperation along similar lines to ALCORA was also occurring among the three countries' intelligence services. Accounts of their meetings, at which Portugal was represented by the Polícia Internacional e de Defesa do Estado (PIDE, later renamed Direcção Geral de Segurança, DGS), provide an interesting, and often critical, account of the military campaigns. They also reveal that the tension among the three countries was often real; intelligence operatives seem to have been more frank and robust in their discussions than their military counterparts. One example suffices: the February 1971 tripartite discussions held in Pretoria. The friction between the South Africans, led by Brigadier P. J. Venter, commander of the South African Police Security Branch, and the Portuguese, led overall by Major Silva Pais, director of the DGS, was evident. PIDE/DGS always seemed content to explain that all negative developments had already been foreseen, as if that was enough to rectify the situation - something which the South Africans wanted done, whatever the consequences. One problem was the Tete district of Mozambique, where the two countries' services disagreed over the scale of the threat to the Cahora Bassa project; another was Angola, where the South Africans had been refused permission to man the border with Zambia, as they were doing in Rhodesia. According to São José Lopes, commander of the PIDE/DGS in Angola, the Portuguese military authorities were to blame for this decision — but he stated that the South Africans would not have met with as much success in Angola as they were having in Rhodesia, since the Zambia-Rhodesia land border was much smaller, given the Zambezi river and the Kariba lake.

The PIDE/DGS, of course, believed that it had the key to winning the war: relegating the army to a defensive role and going on the attack with its own locally raised troops, the Flechas, more suited to a counter-insurgency that demanded prolonged stays in difficult terrain, ambushing the ambushers. These men were allowed to live in separate neighbourhoods, with their families, and were given a host of privileges in return for their loyal service; they were also feted by the Portuguese political authorities, and became the subject of a considerable mobilization campaign, supported by the PIDE/DGS. ${ }^{20}$ Even here, however, South African help, in the shape of military materiel to arm these auxiliary troops, was required. ${ }^{21}$ The PIDE/DGS hoped that these supplies

19 See, for example, ADNPdeA, 'Minutes of a meeting between representatives of the Operations Coordinating Committee and the C in C Moçambique held at Nampula on the 4th August, 1972, at 1640 hours', for a discussion between Rhodesian military leaders and General Kaúlza de Arriaga on the former's ability to operate within Mozambique. Political sensitivities were heightened in the wake of the Mukumbura massacre (September 1971), in which Rhodesian forces had been publicly implicated. ${ }_{20}$ See Lisbon, Arquivo PIDE/DGS, N.I. 7944, Pasta 5, 'Documentos Referentes aos Flechas', for a copy of the 'Estatuto da Liga dos Amigos dos Flechas', an organization led by the secret police which sought to include members of the wider community in fund-raising for the Flechas.

${ }_{21}$ On 12 November 1973, for example, P. W. Botha wrote to his Portuguese counterpart, Joaquim Silva Cunha, confirming Botha's commitment, given to Silva Cunha's predecessor at a meeting of the two 
might be negotiated and orchestrated directly between itself and BOSS, but the Defence ministries were loath to accept this, and generally preserved their primacy over the intelligence services. As was the case with ALCORA, there was a tendency for the intelligence services to grow closer together with the passing of time. In January 1971 General Van den Bergh, the head of BOSS, wrote to his counterpart, Silva Pais, that, since the creation of BOSS, his attention had been distracted, and he had stopped going to the quarterly police meetings of the three countries, which had, it seemed to him, become very routine. Circumstances had changed, however, thanks to an apparent breakdown in the intended detente with Zambia. Van den Bergh wrote asking, ominously: 'are we going to leave matters as they stand and allow Zambia to carry on with her undeclared war on Angola, Rhodesia, Mozambique and South Africa, or are we as Intelligence Services going to do something about it? I think the answer is obvious!'22 The quarterly meetings should continue, he said, but, in addition, there should be higher-level meetings that included Ken Flower, director of the Rhodesian Central Intelligence Organisation (CIO), 'to consider and exchange views on whatever onslaught, threat or dilemma, international or otherwise, our respective countries might be faced with, to prepare evaluations at our level, and to submit recommendations for positive and perhaps joint action by our governments [...] covert action, against whomever you and I and Ken might consider it necessary in whatever form, does not fall into this category - that is something we will decide on our own and execute clandestinely ourselves i.e. with our own staff and resources'.

This, then, was the way out for Portugal, as seen from what might be termed the 'bunker': ever closer cooperation with South Africa and Rhodesia. At long last the international situation seemed to favour the hardliners. Competition between China and the USSR in Africa was causing confusion among the 'frontline' states opposed to colonialism, while a different attitude was developing in Washington. American foreign policy was entering into a pragmatic, realpolitik-inspired phase, under the tutelage of Henry Kissinger. National Security Study No. 39 encouraged the Nixon administration to treat Portugal as a regular ally in the struggle against communism, given that the Portuguese could not be defeated by the nationalist movements and that there were no vital American interests in the region. The changing mood quickly made itself felt. In January 1970, for example, Brigadier Venter, of the South African Police, had noted that 'his country has noticed signs of a more sympathetic attitude from the USA since President Nixon had taken office.. ${ }^{23}$ The Yom Kippur war of 1973 would show once more the enormous value of Portuguese bases, notably in the

men, on 12 September 1973, to an increase in Pretoria's aid to the Flechas to 750,000 rands per year. ADNPdeA, SGDN, box 4385 .

${ }^{22}$ APIDE/DGSL, PR CI (2) N. 6341, Pasta 18, letter, General Van den Bergh to Major Silva Pais, 29 January 1971.

${ }^{23}$ APIDE/DGSL, PR CI (2) N. 6431, Pasta 14, 'Reunião dos representantes das polícias da RAS, Rodésia e PIDE, Salisbury, 21-22 de Janeiro de 1970'. 
Azores, to the United States. Under this new dispensation, the way seemed clear for ALCORA to flourish.

Interestingly, however, there was no consensus within the Portuguese Armed Forces, among those who were 'ALCORA-aware', about the value of the Exercise. There was one instance of a naval officer, involved in ALCORA business, whom Rhodesians and South Africans refused to deal with, given his attitude at a meeting of the Telecommunications Sub-commission. This naval officer appeared not to be 'integrado no espírito ALCORA' [imbued with the ALCORA spirit]; he was not 'animado da boa compreensão e amizade que sempre têm sido observadas nas relações entre os militares dos três países' [moved by the good understanding and friendship which have always been evident between the military men of the three countries]. ${ }^{24}$ More serious, however, were the doubts expressed by General Francisco Costa Gomes, appointed Chief of Staff of the Armed Forces (the most important post in the military hierarchy) in September 1972. A number of documents suggest that, despite being well regarded in Pretoria and Salisbury, he too was not imbued with the 'ALCORA spirit'. In October 1973, for instance, he poured cold water on the notion of an ALCORA Strategic Force, which he saw as a rushed experiment which would weaken Portugal's fighting capability. Writing in advance of the November 1973 ATLC meeting, Costa Gomes was of the opinion that Portugal's representative, General Ivo Ferreira, should be furnished with strict guidelines when it came to this proposed force. ${ }^{25}$ A clearer indication of Costa Gomes's thinking had been produced in March 1973, with an opinion entitled 'Futuro do Exercício ALCORA'. This was a reaction to a document of the same name, whose draft Costa Gomes wanted altered. ${ }^{26}$ Clear from the amendments introduced by Costa Gomes was the desire to preserve autonomy, allowing Portugal to judge when to call for outside help rather than permitting the creation of tripwires which might automatically determine foreign intervention. Costa Gomes also opposed the creation of Permanent Combined Staffs. The reason given was that 'devemos conservar a nossa liberdade de acção não tomando compromissos que tornem difícil a nossa posição política' [we must preserve our freedom of action by not taking on commitments that render difficult our political position]. Costa Gomes finished the document by expressing the view that 'o tempo em relação à ameaça não está no lado dos países ALCORA' [when it comes to the threat, time

24 ADNPdeA, SGDN, caixa 7622, letter, Colonel Eduardo Alberto Silva e Sousa (Secretary of ALCORA Coordinating Commission (Portugal)), to the President of ACOC (Portugal), 26 November 1971.

25 ADNPdA, SGDN, Caixa 7624, 'Constituição de Forças de Reserva e Estratégicas ALCORA', 25 October 1973. This opinion was in direct contradiction of the briefing paper prepared for the Minister of National Defence in May 1973, in advance of a meeting with P. W. Botha: ADNPdeA, SGDN, Caixa 7624, 'Conversações a realizar entre S.Exas os Ministros da Defesa de Portugal e da República da África do Sul', Lisbon, May 1973.

${ }_{26}$ 'Futuro do Exercício Alcora' was distributed as an annex to ACOC/5, the minutes of the 4th Meeting of the Alcora Coordinating Committee, held in Pretoria, in October 1972. See Lisbon, Arquivo Histórico Militar, Fo/oo7/B/44 Caixa 372 (44). 
is not on the side of the ALCORA countries]. Another future member of the Junta de Salvação Nacional which led Portugal in the aftermath of the 25 April revolution, Air Force General Manuel Diogo Neto, was quoted by the American embassy in Lisbon as stating (after his refusal to replace Spínola as Governor of Portuguese Guinea) that 'general feeling among Portuguese in Mozambique [he may have been speaking only of the military] [is] that at some point in the future it would probably be impossible for the Portuguese to continue to control the situation and that at that time territory would be divided up between South Africa, Rhodesia, and Malawi or FRELIMO'. ${ }^{27}$

It should also be noted that doubts about ALCORA, and the strategy being followed, were not limited to the Portuguese; they very much existed in the other ALCORA countries as well, because each member state was still essentially free to determine its military strategy, while Portugal's ability to wage war remained a concern. At the end of 1971, the Odell committee, limited to South African and Rhodesian defence officials, was established to review the deteriorating situation in the Tete district. ${ }^{28}$ Its tone and language reflected a deep unease about Portuguese tactics, the threat from the nationalist movements and the growing menace of communist China. The committee members wanted to bring to the notice of their governments, as a matter of urgency, the imminent danger to the security of southern Africa. Such was the deterioration of the Portuguese position there that the Odell Committee argued that military liaison was not enough: the 'potential danger' required bilateral meetings between Smith and Vorster, 'as a prelude to a meeting attended by them and the Prime Minister of Portugal'. ${ }^{29}$ As an expression of this mounting concern, Ken Flower visited Portugal some two weeks before the April revolution to meet with the Defence Minister, Silva Cunha. Rhodesia, he pointed out, had been considering the possibility of sealing off the Mozambican border - an immense undertaking. It would be easier, it had been concluded, to establish a line in Mozambique such as the Zambezi river from Zumbo through the Cahora Bassa lake to the Indian Ocean - wherein all three countries could concentrate their efforts, while sponsoring the continued development of the Flechas. ${ }^{30}$

27 Secret cable, 16 July 1973, US Embassy in Lisbon to Secretary of State. Consulted at <http://aad. archives.gov/aad/series-description.jsp? $s=4073 \&$ cat $=$ all $\& b c=s l>$.

${ }_{28}$ Grahamstown, Rhodes University, Cory Library, Ian Smith Papers, Top Secret MD/P/11 11 January 1972 - to be opened only by Mr Ian Smith: 'The Odell committee - The Tete district of Mozambique, 28 December 1971'. For evidence of Rhodesian military activity in Tete prior to this report see the account in David Martin and Phyllis Johnson, The Struggle for Zimbabwe: The Chimurenga War (London: Faber, 1981), pp. 3-6.

29 Ibid.

30 ADNPdA, SGDN, Caixa 6179, Ministro da Defesa Nacional, 'Visita do Sr K. Flower, Director da Organização Central de Informações da Rodésia (CIO), 8 Abril 1974’. Tellingly, Flower suggested that such a scheme, if presented by the Rhodesians, would interest South Africa, who, having already been consulted, had given support for an expansion of the Flechas, while reserving a decision on the Zambezi line until after their elections. Reflecting on the conversation, the minister wrote that such a step would send out the wrong signal to everyone north of the line. He also assured Flower that Portugal remained interested in preserving the good relationship which existed among the three 
Similarly, Portuguese and South Africans sometimes kept matters beyond the knowledge of the Rhodesians. In July 1972, the two countries' Defence Ministers met in Lourenço Marques. Various issues were naturally discussed. The final substantive issue was the 'Inclusão da Rodésia nos assuntos da presente reunião' [Inclusion of Rhodesia in the matters arising from the present meeting]. Botha stressed Rhodesia's importance to the defence of Southern Africa, and pointed out that collaboration with Salisbury should be wider than just ALCORArelated questions. The Portuguese minister, Sá Viana Rebelo, while agreeing with Rhodesia's importance, replied that there was no need to inform Salisbury of the creation of a secure communications link between Pretoria and Nampula (where the military command of Mozambique was located) 'dada a natureza secreta dos assuntos a tratar' [given the secret nature of the matters to be dealt with]. When Botha asked if he could inform the Rhodesians of the discussions surrounding the Tete district, which concerned them directly, the Commanderin-Chief in Mozambique complained of the brutality of the Rhodesians when allowed to operate in Portuguese territory, describing one operation 'na qual, segundo acusação da Igreja, mataram muita população inocente, que nada tinha a ver com os terroristas' [in which, according to the Church's accusation, they killed many innocent people, who had nothing to do with the terrorists]. He added that in future, 'as operações em território nacional serão sempre realizadas pelas NT, que obrigarão o inimigo a passar para a Rodésia, onde as tropas deste país o poderá [sic] então eliminar' [operations on national soil will always be conducted by our troops, who will oblige the enemy to cross into Rhodesia, where the latter country's troops can then eliminate it]..$^{31}$ Criticism of ALCORA partners was even made to outsiders; thus the American Consul in Lourenço Marques wrote, on 11 May 1973: 'Portuguese generally believe they know great deal more about counterinsurgency than do Rhodesians/South Africans, despite latter's frequently thinly veiled suggestions they could run Mozambique war better than "slack", "inefficient" Portuguese.'32 In August of that year Max Hastings reported for the Evening Standard on Rhodesian operations deep inside Mozambique. Hastings, who had spent three weeks in Africa, claimed that 400 Rhodesians, supported by helicopters, were rooting out 'terrorist' bases. Hastings was told by one Rhodesian soldier that the 'terrorists' feared the Rhodesian forces, very different in their operations to " "the Portuguese army, who just crash along through the bush shouting and singing deliberately because they do not want to make contact"'. That was not all: "All they are about is persuading us to swap them Rhodesian battledress

countries, noting ALCORA as an example and opposing the creation of parallel means of collaboration outside ALCORA.

${ }^{31}$ ADNPdA, Fundo 3, Série 25, Caixa 58, 'Relatório das conversações realizadas em L. Marques em 11JUL72, entre os Ministros da Defesa de Portugal e da República da África do Sul’, 17 July 1972.

32 Confidential cable, US Consul in Lourenço Marques (Van Oss) to Secretary of State, 11 May 1973. Consulted at $<$ http://aad.archives.gov/aad/series-description.jsp? $=4073 \& \mathrm{cat}=\mathrm{all} \& \mathrm{bc}=\mathrm{sl}>$. 
because they think they will look good in it". 33 The Portuguese Consul-General in Salisbury brought Hastings's article to the attention of the Rhodesian authorities; his interlocutor, Secretary O'Donnell of the Rhodesian Foreign Office, poured cold water on the allegations, but promised to speak to the military command in order to stress the need for members of the armed forces not to comment on any ongoing operations.

As the previous examples show, there were limitations to the links developed at ALCORA level, and these suggest that much of the activity undertaken was misguided, since it did not address the burning issues of the day: the war actually taking place, and its underlying causes. The concentration on conventional warfare in the mid-to-distant future meant that less attention was focused on the problems facing the ALCORA territories, notably Mozambique, in the present; change in this respect came too late to be of use. Moreover when a conventional threat to Angola, from Zaire, seemed to develop, in 1974, it had not been forecast by the ALCORA intelligence apparatus, which was then deemed too slow to deal with the emergency. Cooperation remained secret until the end, because the problems raised by an acknowledgment of links outweighed the advantages of common action. As Admiral Biermann lamented to General Luz Cunha, in February 1974, 'nós como militares concordamos, mas os ministérios dos Negócios Estrangeiros põem, por vezes, dificuldades' [we as military men agree, but the Foreign Ministries, at times, create difficulties]. ALCORA was never able to smooth out the relationship between Nampula on the one hand, and Pretoria and Salisbury on the other, over the situation in the Tete district, which continued to worsen despite Portuguese assurances, and which became the main threat to Rhodesia's security, notably after the closure of the border with Zambia in January 1973. At a tripartite meeting of the intelligence services, held in Lisbon in September 1973, it was concluded that 'the situation in Mozambique is such as to cause deep worry to the South African and Rhodesian governments. It has been suggested that there is a need to re-examine the concept of joint operations, particularly in the common border areas, especially as far as the Tete district is concerned. ${ }^{34}$ It was also agreed that the Flechas experiment had to be extended to Mozambique. The report on the situation in Mozambique, presented by the DGS, was indeed worrying; in the Tete district FRELIMO felt sufficiently confident to attack in large units, of 100-200 guerrillas, and to employ heavy weapons, such as the $122 \mathrm{~mm}$ rockets, south of the Zambezi river. It was feared that it would soon begin an urban guerrilla campaign in Tete town itself. Worse still, FRELIMO had met with little resistance as it moved south towards Vila Pery; in one year, its fighters had moved $200 \mathrm{kms}$ into Portuguese territory with no strain on

33 A summary of this article was sent by the Portuguese Embassy in London to the Ministério dos Negócios Estrangeiros on 20 August 1973. Lisbon, Ministério dos Negócios Estrangeiros, PAA 1322.

34 APIDE/DGSL, Serviços Centrais, Pr. CI(2) n.6341, Pasta 24, 'Reunião dos representantes das polícias da RAS, Rodésia e PIDE, Lisboa, 10-11 de Setembro de 1973’. 
their supply chain - this while making inroads towards the key port of Beira as well, with considerable impact on the morale of the civilian population, white and black. Two months later, at the sixth ATLC meeting, in Salisbury, the delegates listened to a report by a Lieutenant-Colonel Parker of the Rhodesian Army, regarding his corporation's ongoing operations. The presiding officer, Lieutenant-General G. P. Walls, explained that the Rhodesians' operations in Mozambique were being carried out with the complete approval of General Basto Machado (the new Portuguese Commander-in-Chief) and that the cooperation between the two countries was very good. ${ }^{35}$ That these operations, not specified in the minutes, had not resolved the problem was evident from the rest of the deliberations: discussing the possibility of a 'Reserve Anti-Terrorist Force', the Rhodesians argued that terrorism was being contained, not eliminated, and that the time had come to coordinate efforts in order to eliminate terrorism in southern Africa - a stance which led the ATLC to charge PAPO with drawing up plans for precisely such an action.

While only a work-in-progress, the ongoing research into South AfricanPortuguese-Rhodesian links in general, and Exercise ALCORA in particular, casts new and significant light on a number of issues, not least of which, in terms of their importance, are the strains felt within the Portuguese armed forces and the divisions among its upper echelons. On 17 December 1973 the US Embassy in Lisbon reported the 'unravelling' of a right-wing plot to replace Marcello Caetano, no longer seen as trustworthy on the colonial question, led by either former Overseas Minister Adriano Moreira or General Kaúlza de Arriaga. Other members of the plot, which had accelerated over the Christmas break, included General Luz Cunha (the Commander-in Chief in Angola), Franco Nogueira (a former Minister of Foreign Affairs), and Silvino Silvério Marques (a former Governor-General of Angola). Spínola, it was reported, had refused to come on board, and had, in conjunction with his superior, Costa Gomes, scuppered the plot, by informing Marcello Caetano of it and 'drumming up opposition within the military'. Soon Spínola would transform the political scene, with Costa Gomes's blessing, through the publication of his Portugal e o Futuro. At the time of the book's publication (February 1974), Luz Cunha was coordinating the combined Portuguese-South African response to the perceived threat from Zaire, and soon, after the dismissal of Costa Gomes and Spínola, he would be appointed Chief of Staff of the Armed Forces, the highest military office in the land. ALCORA's supporters were at last in control. That the Portuguese armed forces were not united by 1974 is, of course, not news: but we are now beginning to understand rather better the nature of the split, and its international ramifications.

Research for this article was made possible by the support of the Instituto Camões, the British Academy, and the Irish Research Council for the Humanities and Social Sciences.

35 AHML, Fo/oo7/B/44 Caixa 374 (51). 